\title{
EFFECTS OF ANEMIA ON PREGNANCY OUTCOMES AT MANIPAL TEACHING HOSPITAL
}

\author{
Mahato $V^{1 *}$, Shrestha $P^{2}$
}

\author{
Affiliation \\ 1. Lecturer, Department of Obstetrics and Gynaecology, Manipal \\ College of Medical Sciences \\ 2. Assistant Professor, Department of Obstetrics and Gynaecology, \\ Manipal College of Medical Sciences
}

\section{ARTICLE INFO}

\section{Received : 20 June, 2020 \\ Accepted : 24 November, 2020 \\ Published : 22 December, 2020 w}

(C) Authors retain copyright and grant the journal right of first publication with the work simultaneously licensed under Creative Commons Attribution License CC - BY 4.0 that allows others to share the work with an acknowledgment of the work's authorship and initial publication in this journal.

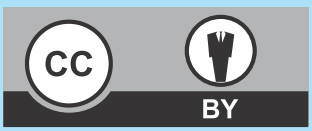

\section{ORA 207}

DOI: https://doi.org/10.3126/bjhs.v5i3.33698

\author{
* Corresponding Author \\ Dr. Vibha Mahato \\ Lecturer \\ Department of Obstetrics and Gynaecology \\ Manipal College of Medical Sciences \\ Email ID: vibha_108@yahoo.com \\ ORCID ID: https://orcid.org/0000-0002-5116-0405
}

\section{Citation}

Mahato V, Shrestha P. Effects of Anemia on Pregnancy Outcomes at Manipal Teaching Hospital. BJHS 2020;1201-1205.

\section{ABSTRACT \\ Introduction}

Anemia is one of the most common disorders affecting the pregnant women in the developing countries like Nepal. Anemia during pregnancy is commonly associated with adverse pregnancy outcomes. Identify inganemia in pregnancy and knowing its common complications will help improve maternal quality care.

\section{Objectives}

The objective-was to assess the effects of anemia on pregnancy outcome at Manipal Teaching Hospital

\section{Methodology}

This cross sectional study was conducted in Manipal Teaching Hospital from September 2019 to April 2020. A total of 200 anemic pregnant ladies attending obstetrics Out Patient Department were selected. Hemoglobin level was taken as criteria for deciding anemia and to classify severity of anemia. Anemia in pregnancy is defined by World Health Organization as hemoglobin level less than $11 \mathrm{gm} / \mathrm{dl}$, and hemoglobin concentration of 10-10.9 g/dl, 7-9.9 g/dl, and $<7 \mathrm{~g} / \mathrm{dl}$ was considered as mild, moderate, and severe anemia, respectively. All were treated depending on severity of anemia and followed up for maternal and perinatal outcome. Data was collected in Microsoft Excel and analyzed by using SPSS version 16 .

\section{Result}

We found moderate anemia in 129 (64.5\%) cases followed by mild in $61(30.5 \%)$ and severe in $10(5 \%)$ cases. Common maternal complications in anemic patients were premature rupture of membrane in 30 (15\%) cases and Urinary Tract Infection in 30(15\%) cases. During puerperium Postpartum Hemorrhage was observed in $12(6 \%)$ and wound infection in 9 (4.5\%) cases of anemic patient. High incidence of adverse fetal outcome in the form of preterm in 39 (19.5\%), Intrauterine growth restriction in $23(11.5 \%)$, Intensive Care Unit admission in 28(14\%), low birth weight in 41(20.5\%) and Intrauterine Death in4(2\%) cases of anemic patients were seen.

\section{Conclusion}

Maternal infection and adverse perinatal outcome in form of intrauterine growth restriction, Intensive Care Unit admission, low birth weight and perinatal death were significantly associated with anemia in pregnancy.

\section{KEY WORDS}

anemia; neonatal; outcome; pregnancy. 


\section{INTRODUCTION}

Anemia is one of the most common disorders affecting the pregnant women in the developing countries. Some degree of physiological dilution in hemoglobin concentration is part of normal pregnancy physiology which is recognized as physiological anemia. ${ }^{1}$ It is important to distinguish pathological anemia from physiologic anemia, as well as to identify other less common causes of anemia that may require treatment. Pathological anemia can have serious adverse effects on maternal and child health. ${ }^{1}$ Anemia is defined by World Health Organization (WHO) as hemoglobin level less than $11 \mathrm{gm} / \mathrm{dl}$ in pregnancy. Anemia was classified based on the WHO criteria as hemoglobin concentration of 10-10.9 g/dl, 7-9.9 g/dl, and <7 g/ dl was considered as mild, moderate, and severe anemia, respectively. ${ }^{2}$ The Prevalence of anemia in pregnant women all over the world is 38\% and is as high as 73\% among pregnant women in Nepal. ${ }^{3,4}$

The causes of anemia during pregnancy in developing countries are multi factorial; these include micro nutrient deficiencies of iron, folate, and vitamins A and B12 and anemia due to parasitic infections such as malaria and hookworm or chronic infections. ${ }^{5}$ Anemic patient are increased risk of maternal morbidity and mortality especially, those with severe anemia. Anemia causes maternal morbidity due to increased susceptibility to infections, physical weakness and increased risk of postpartum hemorrhage. Neonate born to anemic mother encounter negative consequences including low birth weight, preterm birth, intrauterine growth restriction, need of intensive care unit admission and perinatal deaths. ${ }^{1,6}$ Managing anemia in pregnancy will help to prevent adverse fetal and maternal outcomes as well as reduce the need for allogeneic red blood cell transfusion. ${ }^{7}$

Severe anemia causes lot of complication in pregnancy. In Nepal many studies were done on anemia in pregnancy showing high prevalence but relatively few studies has been done to analyze the maternal and fetal outcome. We aimed at finding the incidence of maternal and perinatal complications with mild and moderate anemia in our center.

\section{METHODOLOGY}

This cross sectional study was conducted in Manipal Teaching Hospital from September 2019 to April 2020. Data collection was done after ethical permission from institutional review committee (MEMG/IRC/267/ GA;12/09/2019) and verbal consent of clients. The sample size was calculated using formula,

$\mathrm{n}=\mathrm{Z}^{2} \times \mathrm{p} \times(1-\mathrm{p}) / \mathrm{e}^{2}=1.96^{2} \times 0.67 \times(1-0.33) / 0.07^{2}=0.7909$

$/ 0.0049=173$

Where,

$\mathrm{n}=$ required sample size.

$p=$ proportion $67 \%$, taken from the previous study. ${ }^{8}$

$\mathrm{e}=$ margin of error, $7 \%$.

$\mathrm{Z}=1.96$ at $95 \%$ Confidence Interval.
Therefore, the calculated sample size was173. Adding a nonresponse rate of $15 \%$, the sample size was 199 .

A total of 200anemic pregnant lady attending obstetrics Out Patient Department in third trimester (more than 28 weeks of gestation) for the first time were selected. Exclusion criteria were all pregnant woman less than 28 weeks of gestation, multiple pregnancy, patients with chronic disease such as, hypothyroidism, chronic renal failure, severe cardiac disease, chronic liver disease and chronic lung disease. Physical examination and hemoglobin estimation was done at first visit in third trimester. Pre-tested questionnaire was administered and details like age, gravida, period of gestation, past history of medical illness, menstrual history was collected. Patients were investigated for complete hemogram, urine routine examination and microscopy, stool routine examination and microscopy, peripheral blood smear and any other investigation as and when required. Anemia was classified based on the WHO criteria; HB concentration of $<11 \mathrm{~g} / \mathrm{dl}$ was considered as anemia. Hemoglobin concentration of 10-10.9 g/dl, 7-9.9 g/dl, and $<7 \mathrm{~g} / \mathrm{dl}$ was considered as mild, moderate, and severe anemia, respectively. ${ }^{2}$

According to degree of anemia, all the subjects were treated with either oral iron or blood transfusion and carefully followed in the antepartum, intrapartum and postpartum periods. Finally, the modes of delivery, maternal complications in the form of pregnancy induced hypertension(PIH), premature Rupture of membrane (PROM), Antepartum hemorrhage $(\mathrm{APH})$, infections, postpartum hemorrhage $(\mathrm{PPH})$ and wound infection and perinatal complications in the form of preterm birth, IUGR (intra uterine growth restriction), low birth weight, intensive care unit (ICU) admission and perinatal deaths were noted in all the study participants. Data collection was done after ethical clearance of IRC and verbal consent of patient. The data were recorded in an Excel sheet and descriptive analysis was performed using SPSS 16 version statistical software.

\section{RESULT}

In our study we included 200 anemic patients. We observed that majority of anemic patients (64.50\%) showed moderate anemia followed by mild (30.5\%) and severe (5\%) anemia (table 1).

Table 1: Proportion of severity of Anemia in Study participants $(n=200)$

\begin{tabular}{|l|c|}
\hline Degree of anemia & $\mathbf{n = 2 0 0 = ( \% )}$ \\
\hline Mild anemia & $61(30.5)$ \\
\hline Moderate anemia & $129(64.5)$ \\
\hline Severe anemia & $10(5)$ \\
\hline
\end{tabular}


Table 2: Socio-clinical information of study population $(n=200)$.

\begin{tabular}{|l|l|c|}
\hline \multicolumn{2}{|c|}{ Socio-clinical Variables } & $\mathbf{n = 2 0 0 ( \% )}$ \\
\hline \multirow{4}{*}{ Age } & $<20$ & $10(5)$ \\
\cline { 2 - 3 } & $20-29$ & $119(59.50)$ \\
\cline { 2 - 3 } & $\geq 30$ & $71(35.50)$ \\
\hline \multirow{2}{*}{$\begin{array}{l}\text { Period of gestation } \\
\text { at the time of } \\
\text { delivery }\end{array}$} & $<37$ weeks & $39(19.50)$ \\
\cline { 2 - 3 } Gravida & $\geq 37$ weeks & $161(80.5)$ \\
\hline \multirow{2}{*}{ Mode of delivery } & Primigravida & $80(40)$ \\
\cline { 2 - 3 } & Multigravida & $120(60)$ \\
\cline { 2 - 3 } & Caesarean section & $108(54)$ \\
\hline
\end{tabular}

The mean age of study participants was 27.3 years with standard deviation of 5.2 years. Majority of the anemic patient $(59.50 \%)$ belonged to age group of $20-29$ years. Anemia were more common in multigravida (60\%) and majority (54\%) of patients were delivered through caesarean section. (Table 2 )

\begin{tabular}{|c|c|c|}
\hline Complications & & $n=200(\%)$ \\
\hline \multirow[t]{7}{*}{ Maternal complication } & Premature rupture of membrane & $30(15)$ \\
\hline & Antepartum hemorrhage & $9(4.5)$ \\
\hline & Pregnancy Induced Hypertension & $15(7.5)$ \\
\hline & Urinary Tract Infection & $30(15)$ \\
\hline & Post PartumHemorrhage & $12(6)$ \\
\hline & Blood transfusion & $36(18)$ \\
\hline & wound infection & $9(4.5)$ \\
\hline \multirow[t]{4}{*}{ Perinatal complications } & Preterm birth & $39(19.50)$ \\
\hline & IntraUterine Growth Restriction & $23(11.5)$ \\
\hline & Perinatal death & $4(2)$ \\
\hline & Intensive Care Unit admission & $28(14)$ \\
\hline \multirow[t]{2}{*}{ Birth weight } & $<2.5 \mathrm{~kg}$ & $41(20.5)$ \\
\hline & $\geq 2.5 \mathrm{~kg}$ & $159(79.5)$ \\
\hline
\end{tabular}

Premature rupture of membrane (15\%) and urinary tract infection (15\%) were common complications in anemic patients. Complication in neonate in form of low birth weight were $20 \%$, preterm birth were $19.5 \%$, intra uterine growth restriction were $11.5 \%$, perinatal death were $2 \%$ and admission to intensive care unit were $14 \%$.(Table 3 )

\begin{tabular}{|c|c|c|c|c|c|}
\hline Variables & & $\begin{array}{l}\text { Mild } \\
\text { anemia } \\
\text { (n=61) }\end{array}$ & $\begin{array}{l}\text { Moderate } \\
\text { anemia } \\
(n=129)\end{array}$ & $\begin{array}{l}\text { Severe } \\
\text { anemia } \\
(n=10)\end{array}$ & P value \\
\hline $\begin{array}{l}\text { Age } \\
\text { (Years) }\end{array}$ & $\begin{array}{l}<20 \\
20-29 \\
\geq 30 \\
\end{array}$ & $\begin{array}{l}4(6.6 \%) \\
39(63.9 \%) \\
18(29.5 \%)\end{array}$ & $\begin{array}{l}5(3.9 \%) \\
74(57.4 \%) \\
50(38.8 \%)\end{array}$ & $\begin{array}{l}2(20 \%) \\
6(60.0 \%) \\
2(20.0 \%)\end{array}$ & 0.161 \\
\hline Gravida & $\begin{array}{l}\text { primigravida } \\
\text { multigravida }\end{array}$ & $\begin{array}{l}31(50.8 \%) \\
30(49.2 \%)\end{array}$ & $\begin{array}{l}47(36.4 \%) \\
82(63.6 \%)\end{array}$ & $\begin{array}{l}2(20.0 \%) \\
8(80.0 \%)\end{array}$ & 0.066 \\
\hline $\begin{array}{l}\text { Mode of } \\
\text { delivery }\end{array}$ & $\begin{array}{l}\text { Ceasarean } \\
\text { section } \\
\text { Vaginal delivery }\end{array}$ & $\begin{array}{l}39(63.9 \%) \\
22(36.1 \%)\end{array}$ & $\begin{array}{l}65(50.4 \%) \\
64(49.6 \%)\end{array}$ & $\begin{array}{l}4(40.0 \%) \\
6(60.0 \%)\end{array}$ & 0.140 \\
\hline
\end{tabular}

We found that cases of mild, moderate and severe anemia were more common in the age group of $20-29$ year $(63.9 \%$, $57.4 \%$ and $60 \%$ respectively). Cases of mild, moderate and severe anemia were found in multigravida (49.2\%, 63.6\% and $80 \%$ respectively). Increase association of cesarean section was found in mild anemic cases (63.9\%). (Table 4)
Table 5: Association of maternal complications with

\begin{tabular}{lllll}
\hline Severity of anemia. & & & & \\
\hline Maternal Complications & $\begin{array}{l}\text { Mild } \\
\text { anemia } \\
(\mathbf{n}=61)\end{array}$ & $\begin{array}{l}\text { Moderate } \\
\text { anemia } \\
(\mathbf{n}=\mathbf{1 2 9})\end{array}$ & $\begin{array}{l}\text { Severe } \\
\text { anemia } \\
(\mathbf{n}=10)\end{array}$ & P value \\
$\begin{array}{l}\text { Pregnancy Induced } \\
\text { Hypertension }\end{array}$ & $4(6.5 \%)$ & $11(8.52 \%)$ & 0 & 0.401 \\
\hline $\begin{array}{l}\text { Premature rupture of } \\
\text { membrane }\end{array}$ & $\begin{array}{l}11(18.03 \\
\%)\end{array}$ & $19(14.72 \%)$ & 0 & 0.159 \\
\hline Urinary Tract Infection & $16(26.22 \%)$ & $13(10.07 \%)$ & $1(10 \%)$ & 0.013 \\
\hline $\begin{array}{l}\text { Antepartum } \\
\text { hemorrhage }\end{array}$ & 0 & $9(6.97 \%)$ & 0 & 0.017 \\
\hline Postpartum hemorrhage & $5(8.19 \%)$ & $6(4.6 \%)$ & $1(10 \%)$ & 0.543 \\
\hline Blood transfusion & $3(4.91 \%)$ & $16(12.4 \%)$ & $10(100 \%)$ & 0.0001 \\
\hline Wound infection & $1(1.63 \%)$ & $6(4.65 \%)$ & $2(20 \%)$ & 0.034 \\
\hline
\end{tabular}

We analyzed that postpartum hemorrhage (10\%) and wound infection (20\%) were more in patient with severe anemia, where as pregnancy induced hypertension (8.52\%) and antepartum hemorrhage(6.97\%) were more among patient with moderate anemia. In patient with mild anemia common pregnancy complications were urinary tract infection (26.22\%) and Premature rupture of membrane (18.3\%). Present study observed statistically significant association of urinary tract infection $(p=0.013), A P H$ $(p=0.017)$ and wound infection $(p=0.034)$ with severity of anemia. (table 5)

In present study, $91.5 \%$ patients were treated with oral iron and $8.5 \%$ required blood transfusion during pregnancy. Among them all the patient of severe anemia received blood transfusion and $7(5.4 \%)$ patient of moderate anemia received blood transfusion during pregnancy. Whereas during postpartum period one patient $(10 \%)$ of severe anemia, nine $(6.9 \%)$ patients of moderate anemia and three (4.9\%) patients of mild anemia required blood transfusion, which is statistically significant $(p=0.0001)$ with severity of anemia.

Table 6: Association of perinatal complication with severity of anemia.

\begin{tabular}{lllll}
\hline $\begin{array}{l}\text { Perinatal } \\
\text { Complications }\end{array}$ & $\begin{array}{l}\text { Mild anemia } \\
(\mathbf{n}=61)\end{array}$ & $\begin{array}{l}\text { Moderate } \\
\text { anemia } \\
(\mathbf{n}=129)\end{array}$ & $\begin{array}{l}\text { Severe } \\
\text { anemia } \\
(\mathbf{n}=10)\end{array}$ & P value \\
\hline $\begin{array}{l}\text { Intra uterine } \\
\text { growth } \\
\text { restriction }\end{array}$ & $11(18.03 \%)$ & $9(7.14 \%)$ & $3(30 \%)$ & 0.014 \\
\hline Preterm birth & $11(18.03 \%)$ & $24(18.60 \%)$ & $4(40 \%)$ & 0.24 \\
\hline Perinatal death & 0 & $2(1.55 \%)$ & $2(20 \%)$ & 0.018 \\
\hline $\begin{array}{l}\text { Intensive Care Unit } \\
\text { Admission }\end{array}$ & $3(4.91 \%)$ & $19(14.70 \%)$ & $2(20 \%)$ & 0.007 \\
\hline Low Birth Weight & $8(13.11 \%)$ & $28(21.70 \%)$ & $5(50 \%)$ & 0.024 \\
\hline
\end{tabular}

Whereas we found that fetal complications like intrauterine growth restriction (30\%),preterm birth (40\%), perinatal death (20\%), intensive care unit admission (20\%), low birth weight ( $50 \%$ ) were increased among the patient with severe anemia. And association of fetal complication like Intra uterine growth restriction, perinatal death, Intensive care 
unit admission and low birth weight $(p=0.014, P=0.018$, $p=0.007$ and $p=0.024$ respectively) were statistically significant with severity of anemia. (table 6)

\section{DISCUSSION}

In this study 200 anemic patients were included. We found that majority of the patients had moderate(65\%) anemia followed by mild (30\%) cases of anemia which is similar to study done by L. Gede few et al (60\% and $34.3 \%$ ) and by O. T. Okube et al (70.7\% and $26.3 \%$ ) where majority of the cases of anemia were moderate followed by mild., ${ }^{9,10}$ Whereas Severe anemia among patients in present study was low (5\%) which was similar to study done by singh P et al from western Nepal (4.29\%). ${ }^{8}$

In our study we found that anemia was more common in the age group of 20-29 years (59.5\%) and among the multigravida patients (60\%). This study was comparable to the study done by Ghimire $\mathrm{RH}$ et al where $67 \%$ were of age group 20-29 and 60\% were multigravida. ${ }^{11}$ It is generally believed that anemia in pregnancy increases with rising parity and maternal age. Multigravida may induce anemia by reducing maternal iron reserves at every pregnancy and by causing blood loss at each delivery. ${ }^{12}$

In present study $91.5 \%$ patients received oral iron and $18 \%$ patients received blood transfusion which is similar to study done by Upadhaya N.1 ${ }^{3}$

Common maternal complications in present study was premature rupture of membrane $(15 \%)$ and Urinary tract infection (15\%). This result was comparable to the study done by Upadhaya $\mathrm{C}$ et al and Ghimire et al where Premature rupture of membrane in $26 \%$ and infections in 16 were observed. ${ }^{11,13}$ Whereas with increasing severity of anemia, significant association of Antepartum hemorrhage $(p=0.017)$, Urinary tract infection $(p=0.013)$ and wound infection during puerperium ( $p=0.034)$ was noted. Although we observed increased risk of postpartum hemorrhage $(10 \%)$ in patient of severe anemia but are not statistically significant. Ghimire et al and Dare FO et al also observed significant association of infection with severity of anemia. ${ }^{11,14}$ Low iron level during anemia alters the function of host immune system. In addition, low hemoglobin level causes lower oxygen saturation at peripheral tissue. Delay in wound healing and low infection prevention finally leads to high risk of developing post procedure infection. ${ }^{15}$

In our study we observed high incidence of perinatal complications in form of preterm birth (19.5\%), Intra uterine growth restriction $(11.5 \%)$, Intensive care unit admission (14\%), low birth weight $(20.5 \%)$ and perinatal death(2\%). These were comparable with the study done by Shradha S. Maka et al where preterm (20\%), Intra uterine growth restriction (28\%), Neonatal care unit admission (25\%) and Intra uterine death (3\%) were observed. Our result were also comparable with the observation of Neerja singa let al where preterm birth (17\%), perinatal death (3.5\%), Intensive care unit admission (28.5\%)and low birth weight babies (27.5\%) were seen. ${ }^{16,17}$ We found that perinatal complication was more among the patient of severe anemia and were statistically significant. Anemia decreases the blood flow and lowers oxygen saturation to the uterus and placenta which can be the reason of low birth weight baby and Intra uterine growth restriction among the patient of severe anemia.

\section{CONCLUSION}

From present study it was concluded that anemia in pregnancy was associated with common complication such as urinary tract infection and premature rupture of membrane. Whereas ante partum hemorrhage, wound infection during puerperium, requirement of blood transfusion and perinatal complication in form of Intra uterine growth restriction, perinatal death, Intensive care unit admission and low birth weight were significantly associated with severity of anemia.

\section{RECOMMENDATION}

Anemia during pregnancy is associated with adverse maternal and fetal outcomes. Proper antenatal care and regular visit during pregnancy is required to improve maternal and fetal outcome.

\section{LIMITATIONS OF STUDY}

First limitation was that we have done the hemoglobin estimation at first visit in third trimester and not after that, so we don't know the status of anemia at the time of delivery.

\section{ACKNOWLEDGMENT}

We would like to thank Dr Smita Shrestha, consultant, Department of Obstetrics and Gynecology and Dr Pradeep Bhattarai, consultant, department of pediatrics for their suggestion and support to conduct the study. We like to thank intuitional review committee for providing ethical clearance to conduct this study. We are also grateful for all study participants who took part in the study.

\section{CONFLICT OF INTEREST}

None declared

\section{FINANCIAL DISCLOSURE}

No funding sources 


\section{REFERENCES}

1. Col Madendag I, Eraslan Sahin M, Madendag Y, Sahin E, Demir MB, Acmaz B. The Effect of Iron Deficiency Anemia Early in the Third Trimester on Small for Gestational Age and Birth Weight: A Retrospective Cohort Study on Iron Deficiency Anemia and Fetal Weight. Biomed Res Int. 2019;2019:4. DOI:10.1136/bmjgh-2015000026

2. WHO. Haemoglobin concentrations for the diagnosis of anaemia and assessment of severity. Geneva, Switz World Heal Organ [Internet]. 2011;1-6. Available from: http://www.who.int/vmnis/ indicators/haemoglobin/en/.assessed, may 21,2020

3.. WHO. The global prevalence of anemia in 2011. Geneva: World Health orgnization; 2015.ISBN9789241564960

4.. $\quad$ Dreyfuss ML, stoltzus RJ, sherestha JB, Pradhan EK, LeClerq SC KS. Hookworms, Malaria and vitamins A Deficiency contribute to anemia and iron deficiency amomg pregnant women in the plains of Nepal. Journals Nutr. 2000;130(10):2527-36. DOI: 10.1093/ jn/130.10.2527

5.. Helmy, Elkhouly NI, Ghalab RA. Maternal anemia with pregnancy and its adverse effects. Menoufia Med J [Internet]. 2018;31(1):7. Available from: http://www.mmj.eg.net/article.asp?issn=11102098; year=2018; volume=31;issue $=1$; spage=7; epage $=11$; aulast $=$ Helmy

6. Nair M, Choudhury MK, Choudhury SS, Kakoty SD, Sarma UC, Webster P. Association between maternal anaemia and pregnancy outcomes: A cohort study in Assam, India. BMJ Glob Heal. 2016;1(1):1-9. DOI:10.1136/bmjgh-2015-000026

7. Patterson JA, Roberts $\mathrm{CL}$ BJ et al. Blood transfusion during pregnancy, birth, and the postnatal period. Obs Gynecol. 2014; 123(1): 126-33. DOI:10.1097/AOG.0000000000000054

8. Singh $P$, Khan $S$ and Mittal RK. Anemia During Pregnancy in the Women of WESTERN NEPAL. Bali Med J. 2013;2(1):14-6. DOI: https: // ojs.unud.ac.id/index.php/bmj/article/view/5250
9. Okube OT, Mirie W, Odhiambo E, Sabina W, Habtu M. Prevalence and Factors Associated with Anaemia among Pregnant Women Attending Antenatal Clinic in the Second and Third Trimesters at Pumwani Maternity Hospital, Kenya. Open J Obstet Gynecol. 2016;06(01):16-27. DOI: 10.4236/ojog.2016.61003

10. Gedefaw L, Ayele A, Asres Y, Mossie A. Anemia and Associated Factors Among Pregnant Women Attending Antenatal Care Clinic in Wolayita Sodo Town, Southern Ethiopia. Ethiop J Health Sci. 2015;25(2):155-62. DOI: 10.4314/ejhs.v25i2.8.

11. Ghimire RH, Ghimire S. Maternal And Fetal Outcome Following Severe Anaemia In Pregnancy: Results From Nobel Medical College Teaching Hospital, Biratnagar, Nepal. J Nobel Med Coll. 2013;2 (1):22-6. DOI:10.3126/jonmc.v2i1.7668

12. Adinma, J.I.B., Ikechebelu, J.I., Onyejimbe, U.N., Amilo G. Influence of Antenatal Care on the Haematocrit Value of Pregnant Nigerian Igbo Women. Trop J Obstet Gynaecol. 2002;19:68-70. PMID: 01895117

13. Upadhyay C, Upadhyay N. Effect of anemia on pregnancy outcome: a prospective study at tertiary care hospital. Int J Reprod Contraception, Obstet Gynecol. 2017;6(12):5379.DOI: http://dx.doi.org/ 10.18203/2320-1770.ijrcog20175246

14. Dare FO, Bako AU EO. Puerperal Sepsis: A Preventable Post-Partum Complication. Trop Doct. 1998;28:92-5. DOI: 10.1177/00494755 9802800212.

15. Jonker Femke A.M. B van HM. Anaemia, iron deficiency and susceptibility to infections. J Infect. 2014;69:S23-S27.DOI: 10.1016/j.jinf.2014.08.007

16. Maka SS, Tondare SB, Tondare MB. Study of impact of anemia on pregnancy. Int J Reprod Contraception, Obstet Gynecol. 2017;6(11): 4847. DOI:http://dx.doi.org/10.18203/2320-1770.ijrcog 20174692.

17. Singal N, Taneja BK, Geetanjali Setia KKS. Foetal outcome in pregnant women with anaemia. Bangladesh J Med Sci. 2019;18(01):63-72. DOI: 10.3329/bjms.v18i1.39551 